\title{
Supporting Value Creation by Reducing Cultural Distance as a Barrier to Exporting
}

Thomas Cooney

Technological University Dublin, thomas.cooney@tudublin.ie

Amanda Ratcliffe

Technological University Dublin, amanda.ratcliffe@tudublin.ie

Jane Silver

University of Salford

Follow this and additional works at: https://arrow.tudublin.ie/buschmarart

\section{Recommended Citation}

Cooney, T., Silver, J. \& Ratcliffe, A. (2009) 'Supporting value creation by reducing cultural distance as a barrier to exporting', International Journal of Entrepreneurial Venturing, Vol.1, no. 2.

This Article is brought to you for free and open access by the School of Marketing at ARROW@TU Dublin. It has been accepted for inclusion in Articles by an authorized administrator of ARROW@TU Dublin. For more information, please contact arrow.admin@tudublin.ie, aisling.coyne@tudublin.ie,gerard.connolly@tudublin.ie. 


\title{
Supporting value creation by reducing cultural distance as a barrier to exporting
}

\author{
Thomas M. Cooney* \\ Dublin Institute of Technology, \\ Aungier Street, Dublin 2, Ireland \\ thomas.cooney@dit.ie \\ *Corresponding Author
}

\section{Jane A K Silver}

Enterprise Technology Unit

School of Computing, Science \& Engineering

Newton Building LG 05

University of Salford, M5 4WT, England

J.A.K.Silver@salford.ac.uk

\section{Amanda Ratcliffe}

Dublin Institute of Technology, Aungier Street, Dublin 2, Ireland amanda.ratcliffe@dit.ie

\begin{abstract}
Value creation at the level of the organisation involves balancing the interests of several different stakeholders, with exporting occasionally viewed as a broad-based strategy capable of achieving such equilibrium. However, while much has been written concerning the logistical and economic challenges faced by SMEs wishing to avail of market opportunities abroad, there remains a dearth of information offering solutions to overcoming cultural distance as a barrier to exporting. An EU project entitled 'Passport to Trade' sought to provide greater insight into business culture by collating the customs and subjective norms of all member states within the EU and making the information gathered available through a dedicated website. This practice-orientated paper offers insight into the practical development of this webbased information tool that supports value creation by reducing cultural distance as a barrier to exporting.
\end{abstract}

Keywords: Business culture, cultural distance, SMEs, exporting, Passport to Trade, barriers to growth, value creation

Reference to this paper should be made as follows: Cooney, T.M., Silver, J.A.K., and Ratcliffe, A. (2009) 'Supporting value creation by reducing cultural distance as a barrier to exporting', Int. J. Entrepreneurial Venturing, Vol.1, No.2, pp.205-219

Biographical Notes: Dr Thomas M. Cooney is Director of the Institute for Minority Entrepreneurship (DIT), Research Fellow at the Dublin Institute of Technology, Adjunct Professor at the Turku School of Economics (Finland), founder and former Chairman of INTRE (Ireland's Network of Teachers and Researchers in Entrepreneurship), President of the European Council for Small Business (2009- 
2011), and a Member of European Commission Advisory/Expert Groups. He is a former Visiting Research Scholar at Babson College (US) and at the University of Durham (UK). He has taught, researched, and published widely in the area of entrepreneurship. Further details can be found at www.thomascooney.com.

Professorial Fellow Dr Jane A K Silver lived and worked for many years in an array of European and International countries. Since entering the field of education she has led a wide-range of research projects, mainly related to making the 'world of work' more real for students. She regularly visits Finland as a visiting lecturer and has been invited as a guest speaker to a number of European universities, specifically delivering lectures on working across cultures. As Professorial Fellow in Enterprise Education at the University of Salford she develops enterprise teaching throughout the university and is the Course Director for the Master of Enterprise programmes.

Amanda Ratcliffe received both a BA (Hons) in Politics and German and an MBA from University College Dublin. She worked in language education and in the Marketing sector for many years in Germany before returning to Ireland in 1995. Having initially completed projects as a marketing consultant in the US and Great Britain, Amanda became General Manager of an SME in the recruitment industry in Dublin. She began her lecturing career in 2001 and now specialises in international marketing and strategic management. Her research interests primarily include branding strategies in the retail sector and the challenge of international cultural issues in management.

\section{Introduction}

Value creation is a topic that has received increased attention in recent times as the arrival of a global recession forced stakeholders of economic activity to evaluate what is meant by the term 'value' and how it might be created or enhanced. Additionally, over the past two decades there has been a growing body of research suggesting that small firms wishing to grow should look beyond their home markets when seeking to develop their business. Indeed, an EFER report in 1995 observed that little of the growth enjoyed by Europe's Top 500 firms came from existing products in existing markets, but almost two-thirds of the growth came from entering new markets. A large majority of these companies were active in foreign markets, with exports accounting for $40 \%$ of their turnover, as opposed to the $10 \%$ export activity for SMEs generally. Other researchers have also identified that high-growth firms place a strong emphasis on exporting (e.g. Feezer and Willard, 1990; Storey and Watson, 1994). However, while much evidence exists regarding the positive relationship between exporting and growth (e.g. Wagner, 1995), it is arguable that SMEs frequently have limited access to the additional resources required to operate abroad and have little desire to move beyond their comfort zones. As Nahapiet and Ghoshal (1998) and Smith et al. (2005) highlighted, value creation is more likely to occur if a firm has the organisational capacity to combine and exchange information into new knowledge. Unfortunately, the idea of expansion through exporting is still widely perceived as an intimidating option for many SME owner-managers due to a lack of knowledge about international markets and the lack of organisational capacity to build new knowledge. Owner-managers frequently elect to remain within their domestic market as the perceived fear of the unknown, including one's ignorance of a market's cultural norms, remains a debilitating barrier to exporting. 
As the economic challenges facing SMEs across Europe continue to grow, many owner-managers are considering exporting as a potential strategy in the search to build value creation. When considering the nature of value creation, Lepak et al. (2007) argued that the level of analysis can occur at the level of the individual, organisation or society. They further contended that one's understanding of value creation depended upon the academic lens through which it was being viewed and the identity of the target or user of the value. This research project was primarily focused on developing an information hub that would enable SMEs to grow their businesses through exporting and therefore the principal level of analysis was the organisation. Post et al. (2002) suggested that the primary purpose of an organisation is to create value in many different ways for many different targets, including earnings for owners, pay for employees, benefits for customers, and taxes for society. However, different stakeholders have different views as to what is of value to them and frequently this may require the owner-manager to balance conflicting interests. Accordingly, Lepak et al. (2007) noted that a stakeholder approach requires that organisations take a broader and a longer-term view of value creation. Arguably, exporting enables this view to be adopted for the benefit of all stakeholders.

Whilst expansion can help an SME to secure its position within existing markets and allow it to exploit new opportunities, exporting poses new challenges for owner-managers as businesses reach for unknown markets with limited resources. A European Commission report (2007) highlighted that fewer than one in ten EU SMEs $(8 \%)$ reported turnover from exports, which is significantly lower than the respective share of large enterprises $(28 \%)$. The report found that the main export obstacle for SMEs was the lack of knowledge of foreign markets (13\% of exporting SMEs mentioned this as their prime obstacle), followed by import tariffs in destination countries and the lack of capital (both 9\%). Wright et al (2007) argued that the reasons for not exporting went further and differentiated between those SMEs who were lacking in the resources to export versus those who simply did not have the inclination to do so. They additionally made the point that some SMEs produce goods that are not tradable and therefore may be restricted naturally to the local domestic environment. They further highlighted that there is also a need to consider the nature of the support systems which new ventures can leverage to overcome attitudinal, operational and strategic barriers to internationalisation. This argument corroborates Doole and Lowe's (1997) findings that while some SMEs lack the ambition to move beyond the domestic market, many small firms faced additional, intangible barriers, such as the lack of knowledge, skills and training resources necessary to achieve sustainable trade in international markets. A study by Barker and Kaynack (1992) identified the major perceived barriers to entry for non-exporting SMEs as follows: too much red tape, trade barriers, transportation difficulties, lack of trained personnel, lack of export incentives, lack of coordinated assistance, unfavourable conditions overseas, slow payment by buyers, lack of competitive products, payment defaults, and language / cultural barriers. While Johnson and Turner (2006) argued that it is imperative for a country's economic growth that its indigenous firms develop a strong sense of export activity, the barriers highlighted above offer a daunting challenge to international business, particularly for inexperienced and lesser resourced SMEs. Interestingly, Johnson and Turner noted that it is the intangible barriers, such as language and culture, which frequently pose the greatest challenge to exporting and 
thus highlighted the critical need for enabling owner-managers to understand that their fears are primarily caused by a lack of information. They argued that the removal or reduction of such knowledge barriers during the initial export stages is essential to generating business growth.

According to Steenkamp (2001), the role of culture has long been established as a key environmental factor which underlies differences in behaviours, or as Moran et al (2007) neatly summarised it: "culture counts". Indeed, the failure to take differences of national cultures into account has been the cause of many business failures that are well documented in the literature on international marketing (Ricks, 1993). Johnson and Turner (2006) were clear that one of the biggest barriers facing SMEs was a lack of knowledge, which is influenced not only by an entrepreneur's level of education and experience, but also by their cultural unfamiliarity with target markets. Swift and Lawrence (2003) commented that understanding the culture of the target market was an essential prerequisite of business success - an issue that had already been extensively examined by a number of practitioners and academics: Terpstra (1978), Hallén and Wiedersheim-Paul (1984), Domsch and Lichtenberger (1991), Howe et al. (1990), Feldman and Thompson (1993), Meschi and Roger (1994), Randlesome and Myers (1995), Schneider and Barsoux (1997), and Conway and Swift (2000). Yet despite the multitude of works on this topic, the complexity of business culture defies any simplistic definition, and while the social collectivity and shared nature of culture and cultural values are dominant themes across the literature, one of the key challenges still unsolved is that of defining the borders of a culture. Linton (1945) emphasised that a culture was the configuration of learned behaviour and results of behaviour whose component elements are shared and transmitted by the members of a particular society. Later Child and Kieser (1977) argued that culture may be defined as patterns of thought and manners which are widely shared. However, the boundaries of social collectivity within which this sharing takes place are problematic, so frequently it may make as much sense to refer to a class or regional culture as to a national culture. This point is expanded by Steenkamp (2001) who agreed that the national level is not the only level at which a culture can be defined. He distinguished between cultural groups (which he termed meta-cultures pan-regional, global), national cultures and micro cultures (e.g. defined by locality or shared characteristic such as age) and thereby broadened the manner in which culture can be viewed.

Understanding the culture of an export market is not only critical to one's chances of success, but also to determining the very markets that an owner-manager might target. Ghemawat (2001) contended that, all other things being equal, trade between countries that share a language will be three times greater than between countries without a common language. This argument is supported by the example of Ireland within the EU market (Enterprise Strategy Group, 2004) where, despite being a member of the Euro zone and its proximity to a potential market of over 450 million consumers in continental Europe, the major trading partner for Irish-owned firms continues to be the United Kingdom and the United States. While neither country is in the same currency zone as Ireland (and the U.S. is outside of the EU trading bloc), it appears that Irish entrepreneurs feel more "comfortable" doing business with their more culturally aligned British and American counterparts than with countries whose first language is not English. Indeed this has sparked the anecdotal observation that Ireland is closer to Boston than it is to Berlin. This example also supports Swift's (1999) proposition that there is a correlation between the level of affinity (or "liking") 
that business people feel for a foreign culture and the extent to which they feel psychologically close to that culture.

From a review of the literature on barriers to exporting, it would appear that being prepared and culturally competent are an entrepreneur's best weapons to overcoming cultural distance. Cross-cultural competence is defined as the appropriateness and effectiveness of one's behaviour in an alien cultural environment; it is a function of knowledge, behavioural skills and motivations (Lustig and Koester, 1999). Muzychenko (2006) confirmed that cultural values affect one's cognition and behaviour, so it is imperative for entrepreneurs to develop cross-cultural competence in order to perform effectively when operating across alien cultures. Muzychenko agreed with Man (2005) that assisting entrepreneurs to develop cross-cultural competence may be a more effective long-term strategy for stimulating entrepreneurial activity (rather than using other direct support initiatives), thereby improving the performance of SMEs. Leonidou (2004) suggested appointing managers with an international outlook and emphasised the importance of participation in cross-cultural training and (where possible) the organisation of field trips to foreign markets to gain familiarity with the alien cultures. Oviatt and MacDougall (2005) contended that the learning process itself is also critical for entrepreneurial firms in international markets in helping them to overcome their 'liabilities of foreignness'. They quoted Lord and Ranft (2000) who argued that learning about a new host country was not a smooth process, while also stressing the importance of prior knowledge and learning for international new ventures. Being prepared was additionally emphasised by Moran et al (2007) who reasoned that 'forewarned is forearmed' and accentuated the importance of understanding cultural factors and cultural specifics in order to avoid 'culture shock'. They offered some practical tips on cultural preparation such as carrying out internet research, taking medical advice and seeking out an expatriate mentor. They admitted however, that any investment in cross-cultural training preparation and training can be considerable, a point which underlies the benefit of a free-to-access cultural context translator such as Passport to Trade.

The primary aim of the EU project 'Passport to Trade' was to provide entrepreneurs with a cultural context translator which would assist them in developing cross-cultural competencies, thereby helping them to bridge any cultural distances that they might be experiencing and supporting their programme of value creation. The purpose of this paper is to explain in practical terms the background to the work and how the website came to be developed.

\section{The Passport to Trade Project - Research and Analysis}

The 'Passport to Trade' project was a research initiative funded by the EU Leonardo da Vinci programme (UK/05/B/F/PP-162_358). The primary purpose of the project was to provide an online resource in business cultures and etiquette that would maintain currency with a dynamically changing business environment relative to the existing and future information needs of SMEs. The materials developed by the Passport to Trade team are available in three languages (English, French and German) and were developed in collaboration with business communities and business support organisations based in Belgium, Czech Republic, Finland, Ireland, Italy and the United Kingdom. The information delivered in these materials was designed to support value creation through exporting by providing relevant data to educate users on cultural norms in other countries. The initiative followed directly upon the needs 
established through a predecessor project - the Leonardo da Vinci EMBER project (Effective Marketing for Business in European Regions; reference number: UK/02/B/F/PP-129566). The Passport to Trade project extended the original work of surveys in four countries (Czech, United Kingdom, Italy and Spain) to encompass surveys in all twenty-five EU countries at the time of the inception of the project in 2005. The University of Salford was the academic and project leader, with partner institutions including industry specialists, business support agencies, and academic institutions from across the EU. Work began on the project in November 2005 and was completed in December 2007.

The starting point for the Passport to Trade project was to evaluate the work undertaken on the EMBER project, review current literature and undertake a needs analysis by surveying SMEs in 25 European countries. The surveying of SMEs and their needs in 25 EU countries was conducted in two consequential stages: interviewing and questionnaires. Interviewing was adopted as a research method during the first phase of the project in order to elicit SMEs views on what aspects of conducting business in other European countries needed to be addressed. As a result of these interviews a questionnaire was constructed that could be sent to SME ownermanagers and to identify the most important needs for information and cultural awareness of entrepreneurs when establishing European trade links. Content writing teams were formulated (SPIN in Italy, TIS in the Czech Republic, DIT in Ireland, STRATEX in Belgium, TSE in Finland, University of Salford in the UK) and specific countries allocated to each of the writing teams. Targets were set to send questionnaires to 4 companies in each of the $25 \mathrm{EU}$ (2005) countries giving the potential of 100 needs analysis responses from Europe.

As a result of this survey, a needs analysis was formulated and the framework to address the cultural issues was developed. It included a variety of issues to be addressed, such as business etiquette, business ethics, business practices, even eating out. All the issues are grouped into three main categories: general business environment, business practice and business meeting, and accompanied by analysis of the political and economic environment in a particular country, as Daniels et al. (2007, p.49) maintained that "culture cannot easily be isolated from such factors as economic and political conditions". The first section of the questionnaire concerned general company descriptions such as size, sector, trading experience, etc. The second section, elements of knowledge, contained questions regarding company attitudes towards other cultures and what they felt was important for a business relationship. This section also asked respondents for their opinions on the idea of the Passport to Trade website and discussed other possible methods of delivery. In the third section, open-ended questions sought the factors that SMEs viewed as important for success and allowed respondents to express their experiences regarding international business

\subsection{Stage One - Section One (General)}

Seventy responses were received to the survey and the following analysis is based upon these submissions. Considerable effort was made to target a small number of SMEs from each EU country (4 per country) but despite the efforts of all partners, the response rate was still considered to be quite low. No response was achieved from: Slovakia, Estonia, Slovenia, and Luxembourg. Due to a change in the partnership mid-way through the Needs Analysis phase of the project, data from Austria, Spain, Portugal, Germany, France and Ireland could not be included in the completion of this phase and was used to corroborate the findings from the 15 country responses that 
were achieved. It has to be noted that responses for Poland and Latvia were from one respondent each and only three responses were obtained from the Czech Republic and Latvia. Figure 1 below illustrates a breakdown of the responses received.

\section{PLACE FIGURE 1 ABOUT HERE}

Respondent companies varied in size between 1 and 250 employees, with the majority employing between 10 and 49 people. More than 84\% of participating firms had traded internationally, most commonly with neighbouring countries where cultural differences were least exaggerated. The needs analysis also highlighted that $70 \%$ of respondents had previously traded outside of the EU. It was interesting to note that within these results a West-East divide could be seen, with Western European countries trading with countries such as the U.S. and Canada where cultures had strong similarities, while a similar pattern was reflected by the Eastern European countries that traded with cultures with which they held strong similarities (e.g. Russia).

\subsection{Stage One - Section Two (Elements of Knowledge)}

The interviews and desk research undertaken in both the EMBER and Passport to Trade projects provided the basis upon which the framework for the web-based content and questionnaires were written. In this section of the questionnaire respondents were asked to rate the importance of various aspects of knowledge about potential markets, with Table 1 below representing the results to the questions asked in this section of the questionnaire. Respondents could rate elements as - not necessary for internationalisation, useful, important, or vital. The aspect rated as the most important to successful internationalisation was 'data relevant to my industry/business sector' which $46 \%$ of respondents marked as vital. Perhaps this is not surprising as this requirement could be presumed for domestic markets also. The second highest score was for 'negotiation skills' which again is more of a general business skill than a culture-specific attribute. In equal third position was 'market entry considerations' and 'business ethics/work practice' which is the first mention of any form of local cultural understanding. Thereafter, 'financial concerns', 'legal environment' and 'import regulations' were also ranked highly by respondents. It is arguable that all of these issues are elementary to any good practice of business and therefore an obvious choice, possibly indicating ignorance surrounding the less tangible matters within the practice of international business.

\section{PLACE TABLE 1 ABOUT HERE}

Over one-third of respondents marked having a knowledge of the 'role of family in society', 'medical care/insurance', 'gender differentiation', 'food and drink', and 'religion' as 'not necessary' for exporting. Indeed, the pattern that consistently emerged in the findings was the lack of knowledge regarding the importance of culture in business issues. The results suggested that it was not understood by respondents generally that the standards applicable in the domestic market are not a benchmark for other cultures where religion and family might hold a particularly important role in society. This understated perception of cultural issues in business matters simply reinforced the need for a support system such as Passport to Trade. 
Participants in the research were also offered the opportunity to express cultural issues that they felt might have been overlooked by the survey. The following were the main suggestions offered:

- Variations in environmental protection information and good practice;

- Communications restrictions - language variations within countries;

- Variations in terms and conditions of payments;

- Access and availability of internet and telephone networks;

- Business restrictions and regulations on import/export;

- Interpersonal communication and importance of building trust;

- Traditional power positioning within organisation structures;

- Different marketing structures in countries;

- Information on ambassadors in countries;

- How company networks and partnerships operate within different business environments;

- The importance of history, traditions, and relations to neighbouring countries;

- The use of slang and sense of humour.

Many of the suggestions listed above echo the perceived barriers which were identified by Barker and Kaynack (1992) for non-exporting SMEs. International business is a venture into the unknown for inexperienced owner-managers and the comprehensive response to this section indicated that cultural factors do underlie many of the fears associated with internationalisation.

Another area of questioning centred on the speed of internet connection available to SMEs. When asked which speed of Internet connection SMEs use, $40 \%$ answered 'up to 1 Mbps', the equivalent of a basic ADSL connection. Figure 2 illustrates that technically $97 \%$ of respondents have a decent technological solution to access Internet. While potentially very interesting, the question of how internet speed might be related to overcoming cultural distance was not addressed in this study as it was considered a substantial study in itself. The question was placed there simply to elicit whether SMEs would be able to access online any materials developed.

\section{PLACE FIGURE 2 ABOUT HERE}

These findings indicate that the majority of SMEs are quite capable of accessing the learning materials online, thereby benefiting from the convenience and flexibility of this delivery mechanism. Furthermore, over $68 \%$ of respondents stated they would be happy with a website as a means of delivery, although $38 \%$ requested some other form of support such as CD Rom or PDF documents. The delivery method used will not only allow SMEs and their employees to access training materials remotely at their convenience, but also enable online support by e-mail. While online delivery remains the prime vehicle for the material, in countries where broadband/internet access is slow or not readily available, CD Roms were also made available.

An information tool is only good if it can be efficiently used. The same applies to any advanced technology, and the online environment in particular. According to the European Commission (2006), the successful integration of ICT into education and training systems is still a significant concern of EU leaders and was the subject of e-Europe 2005 policy priority, which focused on leveraging the development and use of e-Learning. In today's economic climate ICT competencies represent the skill needed to adapt to a rapidly changing business environment. The Passport to Trade project created an intuitive and easily accessible web-based learning environment, 
which allows SMEs to obtain quite extensive cultural briefing materials and also share feedback on the quality of such materials. This environment allows the collection and analysis of the search interests of information seekers using a 'semi-intelligent' search procedure. While navigating through the material users are able to indicate their rating and give recommendations on the material provided. It offers a system that can be comfortably utilised by business people of all levels of computer competency.

\subsection{Stage One - Section Three (Successful Business Relationships)}

In this section of the questionnaire respondents were asked to comment on any factors that they considered important for a successful business relationship. The overall response rate of $28.6 \%$ was very low, reflecting the fact that answers had to be original and therefore this section was more demanding in terms of time and linguistic capability. The analysis of these qualitative responses, given the low return, were recorded by country. Countries commented upon were not solely restricted to the EU and included comments on dealings with China, Lebanon, Libya, Japan, India, New Zealand and Saudi Arabia as well as European countries. Many responses were (understandably) subjective as can be illustrated with an example concerning Germany: While one respondent positively rated Germany as "Reliable; good attitude towards time and structure; formal; good business ethics", another respondent felt Germany was "Too protectionist; lack of trust". These issues were further examined during the testing stage of the Passport to Trade website. The assorted view of what makes internationalisation successful (or not) further reflected the importance of a support facility to ensure that the right information is carried to the right culture. Respondents who had experience of cross-cultural trading were aware of the problems that could exist whereas those people who had no prior experience did not rate cultural elements as being important in developing cross border links.

\subsection{Stage 2 - Testing}

The next stage of the project was testing as the accessibility and content of the new website was analysed through qualitative research. Three groups of potential users were tested in the Czech Republic and in the UK: (1) SMEs, (2) business support companies, and (3) third-level business academics/students. In addition, further testing was conducted among a group of expert users in Italy. Additionally, a focus group workshop was held at an international small business conference which enabled a random group of 18 people to test the beta website. Testing was only possible on the English language version of the site so the Czech companies and Italian experts had to be competent in English. Participants were asked to perform tasks such as locating specific points of information. This was timed and the ease or difficulty of navigation monitored. They were also given the opportunity to comment on their experience. In the Czech Republic linguistic difficulties were highlighted, indicating a need for further translation of country material on the site into other languages at a later time. Design and navigation issues were also discussed and suggestions for improvement were built into the development plan for the site.

With $84 \%$ of the total number of survey respondents having first-hand experience of business culture issues and with focus groups based on different types of potential users, it was possible for the website to be designed based on research which had taken careful consideration of the attitudes of owner-managers. The results of the analyses emphasized a significant interest in the Passport to Trade project, and 
reflected a strong need for the initiative. The content of the site received a very positive reaction from participants (all the content pages have a rating system that respondents were asked to complete them) and indicated a desire for more detailed and qualitative information to be made available. This framework was additionally validated using modern internet technologies. Interestingly, the testing of the framework also produced additional indications for meeting the future needs of SMEs. The layout of the website benefited from suggestions made with regards to navigation and clarity, resulting in a user friendly product design, and the feedback from the research facilitated the generation of an appropriately styled and informed resource. The result of all of this work can be found at www.businessculture.org. The Project has become an EU exemplar project and was included in the list of top projects in Europe for 2007.

\subsection{Limitations of this Research}

The Project team recognised that there are a number of limitations to their research. For example, the actual number of responses to the needs analysis was low at seventy, and therefore cannot be viewed as representative of all EU SMEs. Additionally, despite numerous attempts to include SMEs from all $25 \mathrm{EU}$ countries in the first phase of the research, responses were initially only received from 15 countries (although six further countries responded later). In the case of Austria for example, this was primarily due to stringent data protection legislation which makes it extremely difficult to gain access to company databases in that country. The fact that the questionnaire was only available in English was undoubtedly a factor also in attaining low or non-response rates from some countries. In Poland for example, only one response was achieved. This may also prove to be an issue for the final product, given that the information is being delivered in three languages only. However, it was the strong belief of the project partners that the volume of concerns reflected in the responses indicated a strong negative perception of dealing with cultural issues, and that in many ways these apprehensions revealed how significantly the Passport to Trade initiative was needed. The original goal of facilitating further internationalisation and encouraging non-exporters to expand into foreign markets could indeed be achieved. It has to be noted that since this was a multi-cultural project team the interpretation of data was subject to cultural bias dependent upon which partner was co-ordinating the relevant work package.

\section{Conclusion}

The principal outcomes for Passport to Trade were designed to support the development of organisational value creation in unfamiliar cross-cultural business situations. Critical to the project was the ambition to improve existing training materials on business culture by incorporating customs and subjective norms from each country within the EU. Through this action the initiative sought to extensively widen and ease access to training materials concerning business cultures and to create a forum for supplementary training materials. These measures would further advance e-learning facilities and support, thereby improving the skill-base of those SMEs with limited resources who wanted to trade across member states. Through an online environment, Passport to Trade has significantly adapted and improved the availability of vocational training materials accessible to SMEs with limited resources. The online method of delivery was considered a crucial element of the 
project as it allows entry at any remote location and offers unlimited access, as well as an easily downloaded programme. Passport to Trade offers a feasible solution to the problem of cross-culture expansion and facilitates business between the Europe's SMEs by reducing cultural distance as a barrier to internationalisation.

The Passport to Trade initiative, and the accompanying research, holds significant implications for a number of stakeholders. Businesses now have the opportunity to access unlimited information on many aspects of internationalisation through a website that was designed to encourage SMEs to cross borders and expand into other markets. Policy-makers have access to the initiative and can harness its potential to generate a forum for the expression, understanding, and interaction of the concerns and limits facing business practitioners throughout the EU. Academics will find this research to be relevant and current, the continuity of which is made possible through the website. People from many different backgrounds will find that this project will provide a source for information that will continue to benefit the development and growth of SMEs in the EU for years to come.

The Passport to Trade website also has considerable capability for future development. The research undergone indicated not only an interest in the website within EU member states, but also highlighted an interest in the cultures of other markets. In global terms, the potential benefits to SMEs derived from breaking down barriers to worldwide trade could lead to a major growth of the EU as an economic region. Language barriers which challenge the availability of information could also be solved by a further enlargement of the initiative. This opportunity for growth reflects the premise of the entire Passport to Trade project and is an exciting prospect for the future of SMEs.

As SMEs account for approximately $99 \%$ of businesses in the EU, improving the level of vocational training materials and enhancing organisational value creation prospects is essential for diversification and for the economic growth required by the Lisbon agenda. Internationalisation within the EU economic region offers SMEs a considerably expanded market with relatively little commitment and limited consequent risk. This paper highlighted how cultural context can act as a barrier to trade and illustrated the need to improve the climate of understanding between business cultures. The Passport to Trade initiative offers a cultural translator as a solution to this key challenge which faces SMEs entering unknown markets. The convenient online delivery will support value creation for SMEs with limited resources and access to learning materials, which in turn will assist them in developing business relationships in other EU countries and further cultivate a culture of international enterprise. Such a scenario is good for the many different stakeholders who operate within the area of economic activity.

\section{References}

Barker, T. and Kaynack, E. (1992) 'An empirical investigation of the differences between initiating and continuing exporters', European Journal of Marketing, Vol. 26, No. 3, pp.27-36.

Child, J. and Kieser, A. (1977) 'A contrast in British and West German management practices: Are recipes of success culture-bound?' Paper presented at the Conference on Cross-Cultural Studies on Organizational Functioning, Hawaii. 
Conway, T. and Swift, J.S. (2000) 'International relationship marketing: the importance of psychic distance', European Journal of Marketing, Vol. 34, No. 11/12, pp.1391- 1413.

Domsch, M. and Lichtenberger, B. (1991) 'Managing the global manager: predeparture training and development for German expatriates in China and Brazil', Journal of Management Development, Vol. 19, No. 7, pp.41-52.

Doole, I. and Lowe, R. (2004) 'International Marketing Strategy, Analysis, Development and Implementation', Thomson, London.

EFER (1995) Europe's 500: Dynamic Entrepreneurs, EFER, Schipol, Netherlands.

European Commission (2007) Survey of the Observatory of European SMEs - Flash Eurobarometer 196, European Commission, Brussels.

Enterprise Strategy Group (2004) Ahead of the Curve, Forfas, Dublin.

Feezer, H.R. and Willard, G.E. (1990) 'Founding strategy and performance: a comparison of high and low growth high-tech firms', Strategic Management Journal, Vol. 11, No. 2, pp.87-98.

Feldman, D.C. and Thompson, H.B. (1993) 'Entry shock, culture shock: socialising the new breed of global managers', Human Resource Management, Vol. 31, No. 4, pp.345-362.

Ghemawat, P. (2001) Distance Still Matters, Harvard Business Review, Vol. 79, No. 8, pp.137-147.

Hallen, L., Wiedersheim-Paul, F. (1984) 'The evolution of psychic distance in international business relationships', in Hagg, I. and Wiedersheim-Paul, F. (Eds), Between Market and Hierarchy, Department of Business Administration, Uppsala University, Uppsala.

Howe, I.C.K., Tseng, A.T.P. and Teo, A.K.H. (1990) 'The role of culture in training in a multinational context', Journal of Management Development, Vol. 9, No 5, pp.51-57.

Johnson, D. and Turner, C, (2006) European Business, Routledge, Abingdon.

Leonidou, L.C. (2004) 'An analysis of the barriers hindering small business export development', Journal of Small Business Management, Vol. 42, Vol. 3, pp.279302.

Lepak, D.P., Smith, K.G. and Taylor, M.S. (2007) 'Value Creation and Value Capture: A Multilevel Perspective', Academy of Management Review, Vol.32, No.1, pp.180-194.

Linton, R. (1945) The Cultural Background of Personality, Appleton-Century, New York. 
Lord, M.D. and Ranft, A.L. (2000) 'Organizational learning about new international markets: exploring the internal transfer of local market knowledge', Journal of International Business Studies, Vol. 31, No. 4, pp.573-589.

Lustig, M. and Koester, J. (1999) Intercultural Competence: Interpersonal Communication across Cultures, Longman, New York.

Man, T.W.Y. (2005) 'Profiling entrepreneurial learning patterns: a competency approach', Paper presented at the Internationalising Entrepreneurship Education and Training Conference, 10-11 July, Guildford, UK.

Meschi, P-X. and Roger, A. (1994) Cultural context and social effectiveness in international joint ventures, Management International Review, Vol. 34, No. 3, pp.197-215.

Moran, R.T., Harris, P.R. \& Moran, S.V. (2007) Managing Cultural Differences: Global Leadership Strategies for the $21^{\text {st }}$ Century, Butterworth-Heinemann, NH.

Muzychenko, O. (2006) 'Cross-cultural entrepreneurship competence in identifying international business opportunities', Paper presented at the $51^{\text {st }}$ World Conference of the International Council of Small Business, 18-21 June, Melbourne, Australia.

Nahapiet, J. and Ghoshal, S. (1998) 'Social capital, intellectual capital, and the organisational advantage', Academy of Management Review, Vol. 23, No. 2, pp. 242-266.

Oviatt, B.M. and MacDougall, P.P. (2005) 'Defining international entrepreneurship and modelling the speed of internationalization', Entrepreneurship Theory \& Practice, Vol. 29, No. 5, pp.537-554.

Post, J., Preston, L. and Sachs, S. (2002) 'Redefining the Corporation: Stakeholder Management and Organisational Wealth', Stanford University Press, Stanford, CA.

Randlesome, C. and Myers, A. (1995) 'Cultural fluency: the results of a UK survey', Journal of Management Development, Vol. 14, No. 8, pp.42-54.

Ricks, D.A. (1993) Blunders in International Business, Blackwell, Cambridge.

Schneider, S. C. and Barsoux, J-L. (1997) Managing Across Cultures, Prentice Hall, London.

Smith, K., Collins, C. and Clark, K. (2005) 'Existing knowledge, knowledge creation capability, and the rate of new product introduction in high-technology firms', Academy of Management Review, Vol. 48, No. 2, pp.346-357.

Steenkamp, J-B. E. M. (2001) 'The role of national culture in international marketing research', International Marketing Review, Vol. 18, No. 1, pp.30-44. 
Storey, D. and Watson, R. (1994) 'Regional labour market influences on managerial remuneration in small and medium-sized enterprises in England: an empirical analysis', Urban Studies, Vol. 31, No. 8, pp.1407-1418.

Swift, J. (1999) 'Cultural closeness as a facet of cultural affinity; A contribution to the theory of psychic distance', International Marketing Review, Vol. 16, No. 3, pp.182-201.

Swift, J. S. and Lawrence, K. (2003) 'Business culture in Latin America: interactive learning for UK SMEs', Journal of European Industrial Training, Vol. 27, No. 8, pp.389-397.

Terpstra, V. (1978) The Cultural Environment of International Business, South-West Publishing Company, Ohio.

Wagner, J. (1995) 'Exports, firm size, and firm dynamics', Small Business Economics, Vol. 7, No. 1, pp.29-39.

Wright, M., Westhead, P. and Ucbasaran, D. (2007) 'The internationalization of SMEs and international entrepreneurship: A critique and policy implications', Regional Studies, Vol. 41, No. 7, pps.1013-1030. 
Figure 1 - Distribution of SME Responses by Country and Company Size

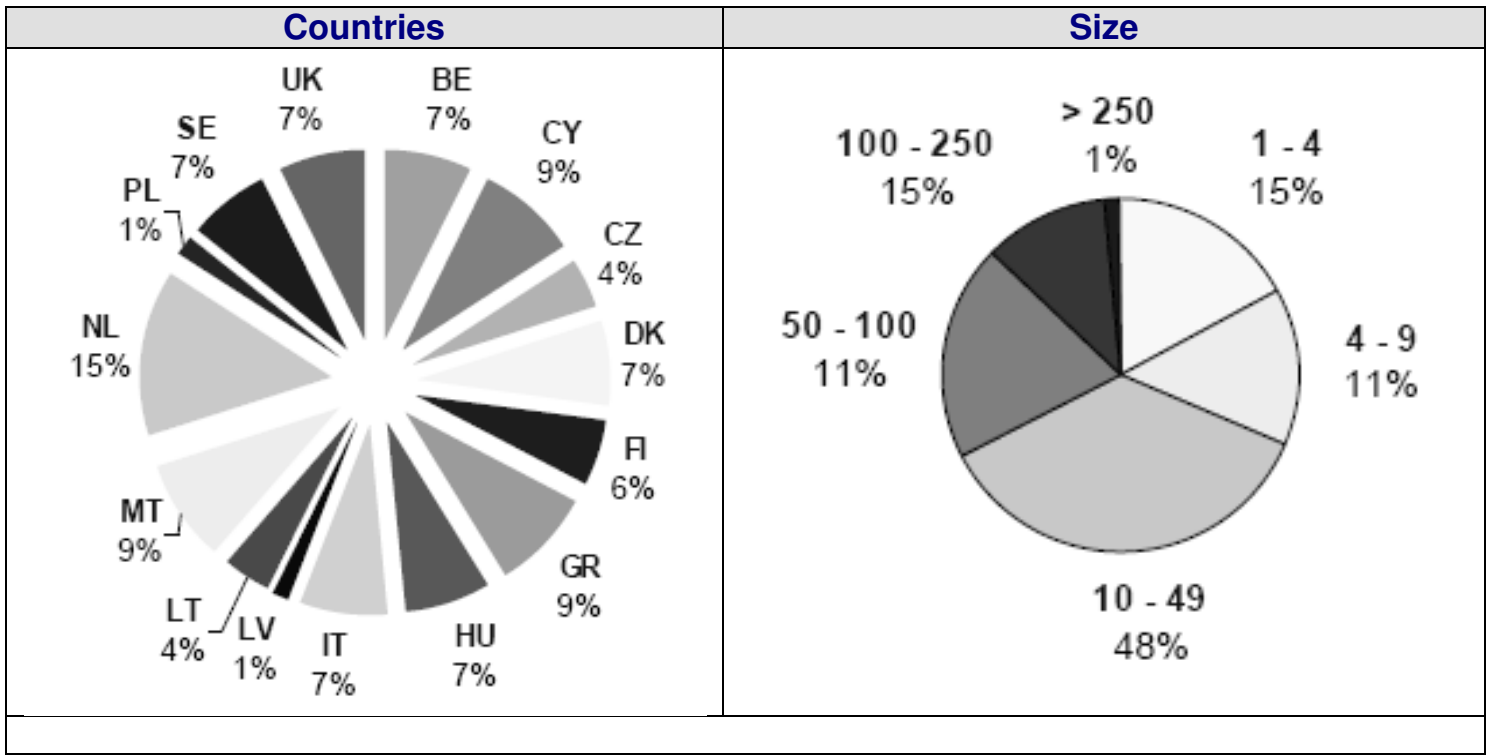

Figure 2 - Respondents' Internet Connection Capability

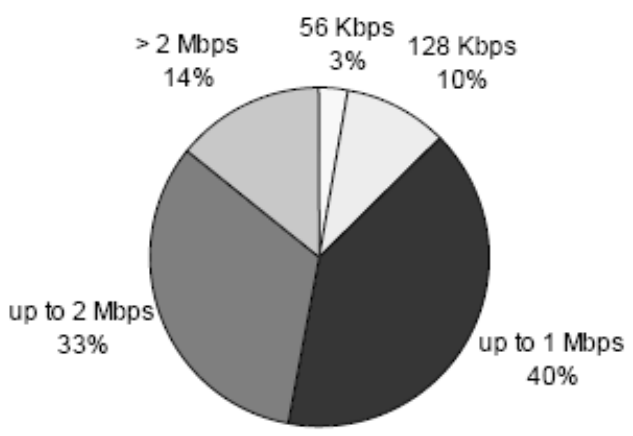


Table 1 - Response to Questionnaire (\% of overall respondents)

\begin{tabular}{|l|l|l|l|l|}
\hline & $\begin{array}{l}\text { Not } \\
\text { Necessary }\end{array}$ & Useful & Important & Vital \\
\hline Economic \& statistical information on a country & 17 & 37 & 31 & 14 \\
\hline Data relevant to industry/business sector & 3 & 13 & 38 & 46 \\
\hline Import regulations/ restrictions & 7 & 33 & 33 & 27 \\
\hline Personal safety issues & 23 & 42 & 20 & 14 \\
\hline Medical care/ insurance & 36 & 39 & 21 & 4 \\
\hline Social organisation/ social status & 21 & 51 & 23 & 4 \\
\hline Role/importance of family in society & 41 & 43 & 20 & 7 \\
\hline Aesthetics (meanings of colour, shape, design etc.) & 31 & 41 & 24 & 3 \\
\hline Religious Views & 39 & 42 & 16 & 3 \\
\hline Gender differentiation & 31 & 41 & 24 & 3 \\
\hline Communication (language both verbal and non-verbal) & 6 & 16 & 59 & 19 \\
\hline Government & 13 & 46 & 28 & 13 \\
\hline Education (attitudes/standards) & 18 & 44 & 29 & 9 \\
\hline Food \& Drink & 32 & 46 & 15 & 7 \\
\hline Meetings \& forms of greetings & 3 & 30 & 48 & 18 \\
\hline Setting up meetings & 1 & 19 & 56 & 24 \\
\hline Conducting meetings & 3 & 30 & 48 & 18 \\
\hline Negotiation skills & - & 10 & 46 & 44 \\
\hline Business ethics/ work practice & - & 19 & 43 & 39 \\
\hline Eating out/ business lunch \& dinner customs & 10 & 49 & 31 & 10 \\
\hline Business etiquette & 3 & 29 & 44 & 24 \\
\hline Political environment & 9 & 44 & 30 & 17 \\
\hline Legal environment & 3 & 22 & 47 & 28 \\
\hline Market entry considerations/restrictions/ requirements & 3 & 14 & 43 & 39 \\
\hline Personnel & 13 & 44 & 22 & 21 \\
\hline Financial concerns & 8 & 20 & 44 & 29 \\
\hline
\end{tabular}

